\title{
Further Reflections on Zhi Qian's Foshuo Pusa Benye Jing: Some Terminological Questions
}

\author{
Jaehee Han ${ }^{1}{ }^{\mathbb{D}}$, Soonil Hwang ${ }^{2, *} \mathbb{\oplus}$, Hyebin Lee ${ }^{2}$ and Jens Braarvig ${ }^{1}$ \\ 1 Norwegian Institute of Philology, 0302 Oslo, Norway; hanj0405@gmail.com (J.H.); \\ jens.braarvig@philology.no (J.B.) \\ 2 Department of Buddhist Studies, Dongguk University, Seoul 04620, Korea; hyebin2@nate.com \\ * Correspondence: sihwang@dgu.edu
}

Citation: Han, Jaehee, Soonil Hwang, Hyebin Lee, and Jens Braarvig. 2021. Further Reflections on Zhi Qian's Foshuo Pusa Benye Jing: Some Terminological Questions. Religions 12: 634. https://doi.org/10.3390/ rel12080634

Academic Editor: Jeffery D. Long

Received: 9 July 2021

Accepted: 5 August 2021

Published: 11 August 2021

Publisher's Note: MDPI stays neutra with regard to jurisdictional claims in published maps and institutional affiliations.

Copyright: (c) 2021 by the authors. Licensee MDPI, Basel, Switzerland. This article is an open access article distributed under the terms and conditions of the Creative Commons Attribution (CC BY) license (https:// creativecommons.org/licenses/by/ $4.0 /)$.
Abstract: Zhi Qian (支謙, fl. ca. 220-257 CE), a prolific Yuezhi-Chinese translator of Indian Buddhist scriptures into Chinese, is widely known for his broad range of styles and terminology. For several decades, his translation activities and his legacy in the history of Chinese Buddhist literature have been a rich field of research, particularly within the context of the transmission of Buddhism from India to China. In the present article, as a follow-up study to "Buddhism for Chinese readers: Zhi Qian's Literary Refinements in the Foshuo pusa benye jing," recently published by the authors in this journal, we offer additional reflections on distinctive features of Zhi Qian's language. We focus on four unusual and interesting renderings in the Foshuo pusa benye jing (佛菩薩本業經, T. 281), namely (1) santu 三塗; (2) shezui 捨罪; (3) kong 空, wu xiang 無想 and bu yuan 不願; and (4) sishi buhu 四時不 護. Through an analysis of these words and phrases, we discuss Zhi Qian's translation techniques and lexical idiosyncrasies, highlighting their significance in our understanding of the dynamics of language contact and change in the early period of the Chinese Buddhist tradition. Thus, the paper investigates some key Buddhist terms as coined by the early translators on the basis of the classical Chinese and illustrates the semantic changes of the Chinese language taking place in the period as well as influence of Buddhist regimes of knowledge.

Keywords: Zhi Qian; Foshuo pusa benye jing 佛菩薩本業經; early Chinese Buddhist translation; translation studies; multilingual terminology

\section{Introductory Remarks-The Historical Interaction between Buddhism and the Chinese Language}

It is well known that the influx of Buddhism into China starting from the beginning of the first century CE changed the Chinese language and Chinese thought in many ways. To absorb the systems of knowledge embedded in Buddhism, terminologies had to be created by adopting existing Chinese terms and using them with new meanings expressing Buddhist concepts. This process had a lasting impact on Chinese culture in general, especially in the fields of religion, literature, philosophy, and even usage in every-day language.

In researching this process, we consider the work of the earliest translators, such as An Shigao (安世高, fl. ca. 148 CE), Lokakșema (Zhi Loujiachen 支婁迦䜟, fl. ca. 168-186 CE), Zhi Qian (支謙, fl. ca. 220-257 CE), and others. Many of their translations have been preserved, and they can serve as materials for assessing this process of Buddhist culturalisation. These outstanding pioneers created terminologies and styles with which to communicate Buddhism to the Chinese. Most of these translators were from Central Asia and knew Sanskrit and other Prakrits, such as Pāli and Gāndhārī, that were used to promulgate Buddhism. However, they were also naturalised Chinese inhabitants who were proficient in literary Chinese and were therefore able to communicate the rich Indian heritage of Buddhism as it was conveyed from India to an interested Chinese public. 
Not all of the early created Buddhist terms would survive, but a surprisingly great part of them became standard throughout the Chinese Buddhist tradition and established the basis for further refinement by later scholars. These newly created terms would also gradually diffuse into the general Chinese language, even the spoken languages, and remained in use not only as learned constructions. ${ }^{1}$

The title of Eric Zürcher's famous Buddhist Conquest of China can also be understood in the sense of a Buddhist conquest of the Chinese language. In the same way that European languages were "conquered" by Greek and Latin, the Chinese language was "conquered" by Buddhist Sanskrit concepts. Thus, Buddhist language and ideologies coexisted with the classical Chinese systems of thinking and knowledge, creating intellectual cooperation in some periods and conflict in others.

Here, we examine a few of Zhi Qian's Buddhist translation equivalents to illustrate the development from their classical meanings into purely Buddhist concepts. This involves exploring their semantic changes, or rather development, in the dynamic process of the "sinicisation" of Indian Buddhist ideology. ${ }^{2}$

\section{Terminological Questions}

Zhi Qian was a prolific Yuezhi-but fully sinicised—-translator of Indian Buddhist scriptures into Chinese, who was active in the third century $\mathrm{CE}$, that is, the embryonic phase of Buddhism in China. He is widely known for his broad range of styles and terminology, particularly for his stylistic and terminological adaptation of already-existing translations by his predecessors, such as Lokakșema, An Xuan (安立, fl. ca. 180 CE), and Yan Fotiao (嚴 佛調, fl. ca. $180 \mathrm{CE}$ ), and also for his refined and elegant style of writing, designed for a high-class readership at the time. As such, his life and works have been discussed by many scholars from various points of view (Tang 1938; Zürcher [1959] 2007; Lancaster 1969; Saitō 2000; Nattier 2003, 2005, 2007a, 2007b, 2008a, 2008b, 2008c; Cheung and Lin 2006; Park 2008; Zacchetti 2010; Karashima 2013b, 2016). However, more detailed studies, especially those dealing with his individual works and their characteristic features thereof, are needed to understand Zhi Qian's translation process, strategies, and techniques, partly because the circumstance of his career as a translator was long and multifaceted, and partly because of his preference for liberal translation.

In the previous paper, entitled "Buddhism for Chinese Readers: Zhi Qian's Literary Refinements in the Foshuo pusa benye jing (Han et al. 2021)," recently published by the authors in this journal, we investigated Zhi Qian's stylistic characteristics as represented in the Foshuo pusa benye jing (佛菩薩本業經, T. 281; henceforth referred to as Benye jing) from the terminological, formal, and conceptual points of view in conjunction with three related texts, the Foshuo dousha jing (佛兒沙經, T.280), the Zhu pusa qiufo benye jing (諸菩薩 求佛本業經, T. 282), and the Pusa shizhu xingdao pin (菩薩十住行道品, T. 283), all of which can be attributed to Lokaksema. In that paper, we argued that Zhi Qian experimented with various strategies to make Buddhism palatable to the upper classes of the society in which he spent his most productive years as a translator and that the Benye jing, with its particularly free translation style, different from the style of his other works, appears to be such an experiment.

In the present paper, we reflect further on distinctive features of Zhi Qian's language by focusing on four noteworthy renderings in the Benye jing, which are not treated in previous studies such as those of Erik Zürcher, Karashima Seishi, and Jan Nattier. ${ }^{3}$ Through an analysis of these words and phrases, we will examine Zhi Qian's translation techniques and lexical idiosyncrasies, highlighting their historical significance and implications in a broader context of the dynamics of language contact.

To this end, we partly rely on Karashima's insightful studies on early Chinese Buddhist translations (e.g., Karashima 2001, 2013a, 2013b, 2016), the results of which can be roughly summarised as follows: (1) Zhi Qian's translation procedure can be described as "sinicising" already-existing translations. That is to say, he produced an elegant and refined translations 
by modifying an earlier translation written in more readable Chinese; ${ }^{4}(2)$ the underlying language of Zhi Qian's works is Gāndhārī or Prakrit containing Gāndhārī elements.

These results have greatly contributed to our understanding of Zhi Qian's translation style and vocabulary. However, it should also be noted that these results are not drawn from an analysis of the Benye jing, but of his other works, such as the Da mingdu jing 大明度 經 (T. 225), the Wuliang qingjing pingdengjue jing 無量淨平等覺經 (T. 361), and the Weimojie jing 維摩詰緗 (T. 474), all of which are preserved in Indic languages. In the case of the Benye jing, there is no extant Indic original. Thus, this study refers to the Tibetan version of the larger Buddhāvatamsaka, the Sañs rgyas phal po che (D 44), translated in about 800 CE by two Indian masters, Jinamitra and Surendrabodhi, and the Tibetan translator-editor Ye shes sde, from which we can draw conclusions concerning the Indic text that underlies the Tibetan translation. ${ }^{5}$ When necessary, we also consult Zhi Qian's other works, the Da mingdu jing, the Weimojie jing, and the Faju jing 法句經 (T. 210), and their parallels in Sanskrit, Pāli, and Gāndhārī if needed.

\subsection{San Tu 三塗: The Three Times}

Buddhism, with its metaphysics of the "three times", presented a highly abstract and philosophically complex concept of time, differing somewhat from the more concrete classical Chinese concept, reflected in terms connected with the concepts of generations, dynasties, years, seasons, months, and days. ${ }^{6}$ The term san $t u$ 三塗, literally meaning "three routes," is Zhi Qian's rendering of the Sanskrit ${ }^{7}$ tryadhvan (the three times), i.e., past, present, and future (cf. BHSD, s.v. tryadhva(n)). Adhvan (G. adhvana; P. addhan) is a complex term that has different meanings in different contexts, for example, "way", "journey", "method", and "time" (cf. MW, s.v. adhvan), ${ }^{8}$ of which the original meaning appears to be "road." In the Buddhist context, however, this term is generally used in connection with the concept of time (cf. BHSD, s.v. adhvan), and Chinese Buddhist translators, beginning at an early stage, have successfully conveyed this meaning. For example, the late third-century translator Dharmarakșa (Zhu Fahu 箨法護, fl. ca. 280-308) renders the term tryadhvan as san shi 三世 (the three periods), which is the most widely accepted by later translators (Karashima 1998, p. 370, see also Kumārajīva's and Xuanzang's translations below). It is noteworthy in this regard that Zhi Qian translated tryadhvan as san tu 三塗 in the Benye jing as well as in his other works since the term san tu 三塗 is often interpreted as referring to the three unfortunate destinies (trayo durgatayah) —namely, hell beings (naraka), animals (tiryag), and hungry spirits (preta) - because the character $t u$ 塗 has a negative meaning, "mire". ${ }^{9}$ Let us first look at the following examples, taken from the Weimojie jing 維摩詰 經 (T. 474), in which Zhi Qian alone understands tryadhvan in the sense of "way" (see the underlined parts): ${ }^{10}$

1. VknSkt. 40b1: yathāvadmaitrī tryadhvasamataȳ̄

Zhi Qian (T. 474, 528a25): 行等之慈等于三塗

Kumārajīva (T. 475, 547b16-17): 行等之慈等三世故

Xuanzang (T. 476, 573a2-3): 修如實慈三世等故

VknTib. 209b3: dus gsum mñam pa ñid kyi phyir ci bžin pa ñid kyi byams pa'o

2. VknSkt. 45b1: tryadhvasamatikrāntā hi bodhih

Zhi Qian (T. 474, 529b9-10): 夫三塗等且如

Xuanzang (T. 476, 574c24-25): 無上菩提超過三世

VknTib. 213b6: byan chub ni dus gsum las yan dag par'das pa'o

${ }^{*}$ No parallels in Kumārajīva's translation (T. 475).

In the Benye jing, the term san tu 三塗 appears six times (T. 281, 446c8, 449b3, 450b15, 450c4, 450c17), in each case corresponding to guoqu danglai jinxianzai 過去, 當來, 今現在 in Lokaksema's translation (T. 280, 445a19-20; t. 282, 453c11-12; T. 283, 455c22-23, 456a25-26, $456 \mathrm{~b} 22)^{11}$ and to dus gsum (three times) or 'das pa dan் $\mid$ ma 'ońs pa dań $\mid$ da ltar byuñ ba (past, 
future, and present) in the Tibetan version (D185, 256b4, 218b6, 250a1-2,251b7). ${ }^{12}$ We give three examples:

1. Zhi Qian (T. 281, 446c8-9): 三塗之事, 靡不貫達。 Lokakșema (T. 280, 445a19-20): 皆入過去當來今現在法中。

Tib. (D185, 256b4-5): 'das pa dan் | ma 'oñs pa dan் | da ltar byuñ ba la dpyod pa śa stag dan thabs cig go

2. Zhi Qian (T. 281, 449b2-3): 若欲入水當願䍃生 身口意淨 等於三塗 [Var.: 若=如 (三宮、聖、聖Z)]

Lokakṣema (T. 282, 453c10-12): 菩薩入水時, 心念言: 十方天下人皆使入佛智慧中， 過去當來今現在悉平等。

Tib. (D185, 218b6-7): chu 'bog pa'i tshe byan chub sems dpas sems can thams cad dus gsum mñam pa ñid kyis thams cad mkhyen pa'i ye śes la 'bogs par gyur cig ces sems bskyed do

3. Zhi Qian (T. 281, 450c17): 學佛三塗無際之慧。

Lokakșema (T. 283，456b22-23): 一者，過去當來今現在，無端亟從佛學。[Var.: 亟 $=$ 底 (三、宮)]

Tib. (D185, 251b7): dus gsum gyi ye shes brjod pa mdzad do

As we will see below, Zhi Qian seems to have had access to Lokakṣema's translation while working on the Benye jing. He appears to have deliberately chosen the term san $t u$ 三塗 to translate tryadhvan or a similar expression instead of using the set of words guoqu danglai jinxianzai 過去, 當來, 今現在 (past, future, and future), which are semantic loanwords from atīta (gone by), anāgata (not come), and pratyutpanna (just arisen) (Feng 2004).

Thus, Zhi Qian's translation of the term adhvan, is based on the etymological meaning of the term $t u$ 塗, road. However, other translators, such as Lokaksema, Kumārajīva, and Xuanzang have employed the metaphorical sense, namely time, as reflected by shi 世.

However, Zhi Qian did not always use the term san tu 三塗 for tryadhvan. In his other works, such as the Ban nihuan jing 般泥洹經 (T. 6, 184c15), the Fan moyu jing 梵摩渝經 (T. 76, 885b29, 885c5), and the Yizu jing 義足緢 (T. 198, 176b6, 180b29), he used a different term, san shi 三世 (the three times) instead. The term san shi 三世 originally referred to "three generations" in the classical Chinese language ${ }^{13}$ but the word was used in the Buddhist translations to refer to the Indian concept of the three times of past, present, and future. ${ }^{14}$ As such, it was widely accepted by later Buddhist translators, including Dharmarakșa, Kumārajīva, and Xuanzang, and the meaning and usage in classical Chinese changed over time in the context of and under the influence of Buddhism.

As for the word san tu 三塗 as Zhi Qian's rendering of the three times, it is also notable that the same usage of the term san $t u$ 三塗 occurs twice in the first chapter of the $D a$ mingdu jing, once in the interlinear commentary (T. 225, 481a24, 481b2). ${ }^{15}$ Modern scholars generally agree that the first chapter, Xing pin 行品 (T. 225, 478b20-482a26), ${ }^{16}$ is not Zhi Qian's work (Lancaster 1969; Nattier 2008a). According to Zacchetti (2010, pp. 154-60), the interlinear commentary is related to Kang Senghui 康僧會 (fl. ca. 249-280) or his circle, active in Jianye 建業, the capital of the Wu dynasty. More textual evidence is needed; however, a more comprehensive and systematic investigation of the term san $t u$ and other similar cases may shed further light on the question of who translated the Da mingdu jing.

\subsection{Shezui 捨罪: To Leave the Secular Life}

Karashima has shown that the underlying Indian texts used by Zhi Qian were transmitted into China in Gāndhārī or a Prakrit close to Gāndhārī and that, in the process of translation, Zhi Qian confused such vernacular or colloquial forms with those of the standard Sanskrit. ${ }^{17}$ In the Da mingdu jing (T. 225), for instance, he often used the word shui 水 (water) where the Sanskrit equivalent is $\bar{a} b h \bar{a}$ (splendour, light). The Gāndhārī form of 
Sanskrit $\bar{a} b h \bar{a}$ is $a v a$, and the Gāndhārī form of Sanskrit āpas (water) is also ava. Therefore, it is highly probable that here, Zhi Qian mistakenly translated Gāndhārī ava as "water", when it should be understood as "light". Specifically, the Zhi Qian's renderings for the heavens related to the second dhyāna, viz. shuiwei tian 水微天 (heaven of subtle water), wuliangshui tian 無量水天 (heaven of unlimited water), and shuiyin tian 水音天 (heaven of water sound), (T. 225, 485a12) should have been * guangwei tian 光微天 (heaven of subtle light), wuliangguang tian 無量光天 (heaven of unlimited splendour), and guangyin tian 光 音天 (heaven of radiant sound), as these terms correspond to paritttābha, apramānābha, and ābhāsvara, respectively (Coblin 1983, p. 244; Nattier 2008c; Karashima 2016).

The same pattern of confusion is also found in the Benye jing. Before focusing on the case of the term shezui 捨罪, we first give four examples, presumably arising from the confusion between Gāndhārī/Prakrit and Sanskrit in order to verify the possibility that the Benye jing was also translated from Gāndhārī or a Prakrit that is similar to Gāndhārī: (a) the same heaven names, shuiwei tian, 水微天, wuliangshui tian 無量水天, and shuiyin tian 水音天, occur in the first chapter; ${ }^{18}$ (b) the word jingjin 精進 (effort) attached to the names of various buddhas, such as Ru jingjin 入精進, Xing jingjin 行精進, and Jin jingjin 盡 精進, probably resulted from the confusion between a certain Prakrit form related to vid(to know) and the Sanskrit virya (G. viya, viriya, cf. GD, s.v. viriya). ${ }^{19}$ This is supported by the Tibetan and later Chinese equivalents rig byed and $z h i$ 智 in the corresponding passages in the larger Buddhāvatamsaka (D44, 177a1-178a7; T. 278, 418b19-c28); (c) the word shou 首, used in bodhisattvas' names, like Jingshou 敬首, Zhishou 智首, and Baoshou 寶首, reflects Zhi Qian's confusion between the Prakrit form of Skt. śrī (glory) and that of Skt. śira (head) (Karashima 1992, p. 277); (d) the word lin 林 (forest), included in the names of buddhaksetras, reflects Zhi Qian's interpretation of the term vana as "forest." However, the term $m d o g$ (colour, appearance) is found in the corresponding passages in the Tibetan version (D44, 177a1-178a7). The Sanskrit equivalent of Tib. mdog is varna, and, in the sound changes from Sanskrit to Gāndhārī, the alveolar tap $r[r]$ can undergo complete assimilation to a following consonant (Baums [2010] 2019, pp. 6-7). Therefore, we can assume that G. vana was differently interpreted by Zhi Qian and by those who produced the Sanskrit manuscripts on which the Tibetan is based..$^{20}$

We now turn to the expression shezui 捨罪, which literally means "to abandon sin". In the Benye jing, it corresponds to pravraj-, which literally means "to go forth" but refers to "the act of leaving the secular life," or rather "the lower ordination." The term occurs only once in the Benye jing, but, with its Sanskrit, Gāndhārī, Pāli, and Tibetan equivalents, it is more common in the Faju jing (T. 210). ${ }^{21}$ Let us first take a look at the following passage from the Benye jing and its parallels in Lokakșema's translation and the Tibetan Buddhāvatamsaka: 22

Zhi Qian (T. 281, 447c13-14): 請求捨罪 當原衆生 得成就志 學不中悔.

[When a bodhisattva] seeks to become a śramana (lit. to get rid of sins), he should wish for all living beings to attain accomplishment and resolution without quitting in the middle of learning.

Lokakșema (T. 280, 451c17-18): 菩薩索作沙門時，心念言: 十方天下人皆使所至到， 悉令得成就, 莫復中悔止.

When a bodhisattva seeks to become a śramana, he thinks: may all livings beings reach and attain accomplishment without quitting or halting.

Tib. (D185, 213b1-2): rab tu 'byun bar gsol ba'i tshe | byan chub sems dpas sems can thams cad bar chad med cin phyir mi ldog pa'i chos can du gyur cig ces sems bskyed do I I

When seeking the lower ordination, the bodhisattva should wish for all living beings to be endowed with the irreversible dharma (avaivartyadharma) without any obstacles.

Given the context and structure, namely the bodhisattva's activity and the related wish for all beings' benefit, one can easily observe that the underlined phrases agree with 
one another. Yet it is still unclear why the term shezui 捨罪was chosen to translate the Indic word underlying zuo shamen 作沙門 and rab tu 'byun ba, which is probably a certain Gāndhārī or Prakrit form of Skt. pravraj- (to become a monk). A possible explanation is that Zhi Qian figuratively rendered Skt. pravraj- as "to abandon sins" in the light of the fact that living a secular life inevitably entails vices. Fortunately, however, the term shezui 捨 罪also appears several times in another of Zhi Qian's works, the Faju jing, and its use there can shed further light on this issue, as the Faju jing is currently available in various Indic versions, including Gāndhārī. Let us examine the following two verses and their parallels:

1. DhpChi. T.210, 569c25-26: 學難(a)捨罪難 居在家亦難 會止同利難 難難無過有 [Var.: 難難=艱難 $($ 三 $)]$

DhpG. 262: drupravaï druabhiramu druajāvasana ghara I dukhu samanasavaso dukhanuvadida bhava.II

DhpP. 302: duppabbajjam durabhiramaṃ durāvāsā gharā dukhā | dukkhosamānasaṃvāso

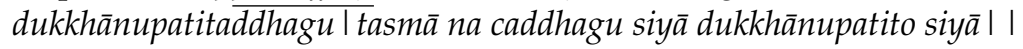

UvSkt. 26, 2: duṣpravrajyam durabhiramam duradhyāvasitā grhhāh | duhkhāsamānasaṃvāsā duhkhāś copacitā bhavāh| |

UvTib. 219a4: dge sbyon spyod pa ji ltar bya I I ñes par rab byun ñes rtsom byed pa dag | I sdug bsrial mñam med sten pa dag | | yan் srid sdug $\overline{b s \dot{n a l} \operatorname{sog} s}$ par zad | |

* No parallels in DhpBHS.

2. DhpChi. T.210 569a7-8: 謂(b)捨罪福 淨修梵行 慧能破惡 是爲比丘 [Var.: 福=業 (明)]

DhpG. 68: yo du (c)baheti pavana vadava brammayiyava I saghaï caradi loku so du bhikhu du vucadi o I I

DhpP. 267: yo 'dha puñ̃nca (d)pāpañ ca bāhetvā brahmacariyavā I sañkhāya loke carati sa ce bhikkhū 'ti vuccatil ।

* No parallels in DhpBHS, UvSkt, and UvTib.

Here, it is notable that in the first of the verses above, (a) shezui 捨罪 is used in the sense of "leaving the secular world", corresponding to Skt. pravraj- (e.g., Skt. pravrajya, pravrajita; P. pabbajjā, pabbajita; Tib. rab tu byuin ba), while in the second verse, (b) shezui directly refers to its literal meaning, as seen in the Pāli equivalent in the second verse (d) pāpañ ca bāhetvā (keeping away from sins). Another noteworthy point is that the Gāndhārī form of Skt. pāpa (evil, sin) is pava, as found in the phrase (c) baheti pavana in the second verse (see also GD, s.v. pava). In the sound changes from Sanskrit to Gāndhārī, the clusters of plosives followed by $r$ [ $]$ are generally unchanged (Baums [2010] 2019, pp. 7-8); accordingly, the regular form of Skt. pravraj- in Gāndhārī is pravaj(or -y)- (e.g., pravaja, pravayadi). ${ }^{23}$ However, irregular changes are also attested, for instance, pavaja, pavaje, parvaja for pravaja and pavayadi, parvayadi, padaïdi for pravayadi (cf. GD, s.v. pravaja, pravayadi). Therefore, it is possible that the supposed Indic original form that Zhi Qian translated was pavaj(or -y)- (e.g., pavaja, pavayadi). Furthermore, he may have rendered it as shezui 捨罪 by adopting the meaning of G. pava (evil, sin). However, it is still unlikely that Zhi Qian failed to understand the meaning of the term since he also used the expression zuo shamen 作沙門 (to become a śramana) in the Benye jing (T. 281, 447c19-20) shortly after the citation above (see the underlined passages):

\section{Zhi Qian (T. 281,447c19-20): 已作沙門 當原衆生 受行佛意 開導天下}

Having become a śramana, he should wish for all living beings to receive and practice the disposition of the Buddha, which guides beings in the world.

Lokakșema (T. 280,451c25-27): 菩薩作沙門時，心念言: 十方天下人皆使作沙門時， 令如佛悉度十方天下人.

When a bodhisattva becomes a śramana, he thinks: may all living beings, when they become śramanas, save others as the Buddha did. 
Tib. (D185, 213b3-4): rab tu 'byun ba'i tshe byan chub sems dpas sems can rnams skye bo thams cad yons su skyon ba'i phyir I de bźin gśegs pa'i rab tu 'byun bar rab tu byun bar gyur cig ces sems bskyed do I I

When taking ordination, the bodhisattva should wish for living beings to take ordination (in the same way) as the tathāgata took ordination, (namely,) in order to protect all beings.

We can see here that Zhi Qian adopted Lokakșema's rendering zuo shamen 作沙門 and added the particle $y i$ 已, indicating the completion of an action. It is clear that yi zuo shamen has the same meaning here as shezui in the first verse from the Faju jing that is quoted above. Some other examples can be found in Zhi Qian's translations of the Weimojie jing and the Faju jing:

1. VknSkt. 19a3: iyam ucyate pravrajyā I ya evam pravrajitās te supravrajitāḥ |

Zhi Qian (T.474, 523b14): 為是故作沙門

Kumārajīva (T.475, 541c22): 若能如是是真出家

Xuanzang (T.476, 563a14): 若能如是名真出家

VknTib. 190b6: de ni rab tu byuñ ba źes bya I gañ dag de ltar rab tu byun ba de dag ni legs par rab tu byun ba'o I ।

2. DhpChi. T. 210, 567a25-26: 觀行忍第一 佛説泥洹最 捨罪作沙門 無䔷害於彼

DhpP. 184: khantī paramam tapo titikkhā nibbānam paramam vadanti buddhā I na hi pabbajito parūpaghātī samaño hoti param vihethayanto I I

DhpBHS. 239: khāntī paramam tapo titikkhā nibbānam paramam vadanti buddhā I na hi pravrajito paropaghātì śamano hoti pare vihesayāno | |

UvSkt. 26, 2: kṣāntih paramam tapas titīkṣā nirvānam paramam vadanti buddhāh | na hi pravrajitah paropatāpi śramano bhavati param vihethayan vai । I

UvTib. 232b3-4: bzod pa dka' thub mchog ste bzod pa ni I I mya nan 'das pa mchog ces

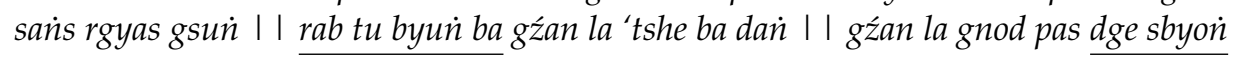
ma yin no | |

* No parallels in DhpG.

Two points are noteworthy here:

(1) Zuo shamen in Zhi Qian's translation of the Weimojie jing was later replaced by Kumārajīva with chujia 出家, literally meaning "to leave home", and this is also the translation adopted by Xuanzang. ${ }^{24}$ Regarding the expression zuo shamen 作沙門, here, it is uncertain whether Zhi Qian learned it from Lokakșema's translation, as seen in the Benye jing (T. 280, 451c25-27), or whether he borrowed it from the older translation of the $V i$ malakīrtinirdeśa by Yan Fotiao 嚴佛調 (fl. ca. $180 \mathrm{CE}$ ), now lost, on which Zhi Qian's translation is perhaps based (Karashima 2016). Yet zuo shamen does not appear in the Fajing jing 法鏡經 (T. 322), the only surviving text attributed to Yan Fotiao (Nattier 2008b, p. 177).

(2) In Zhi Qian's translation of the Faju jing, the two terms, shezui and zuo shamen, appear together. Since there is nothing in this verse in any of the texts that suggests the literal meaning of the word shezui 捨罪 (to abandon sin), we can assume that shezui is used in the sense of pravraj-, and thus that the phrase shezui zuo shamen 捨罪作沙門 in the third pāda corresponds to the Sanskrit expression pravrajito ... śramano bhavati (P. pabbajito ... samano hoti; BHS: pravrajito ... śamano hoti; Tib. rab tu byun ba ... dge sbyon ... yin no).

In sum, we can learn from the examples examined so far that Zhi Qian intentionally rendered the Gāndhārī (or Prakrit) form of pravraj- as shezui 捨罪 even though he knew the expression zuo shamen 作沙門, which appears in the Benye jing and his other works. Further, the underlying Indic form of shezui may be pava-, from which Zhi Qian could derive the meaning of "evil, sin" and not merely his figurative interpretation of "leaving a secular life (or becoming a monk)" as "abandoning sins." 
In Indian hermeneutics, as practised by Hindu and Buddhist writers and commentators alike, one would explain words with etymologies that were sometimes not at all in accordance with scientific etymologies. With pāpañ ca bāhetva (doing away with sin) as an etymology for pravrajya is definitely such a case, and one may indeed call the procedure a folk-etymology or pseudo-etymology. However, a better term might be "intentional etymology", as in its Buddhist context, it better expresses the intention of the word pravarajy $\bar{a}$, though its (true) etymological reference is "leaving (home)".

Thus, we would like to contend that Zhi Qian's choice of the Chinese equivalent shezui is based on this principle of Indian hermeneutics to convey the Buddhist intention of the expression rather than a misunderstood reading of the Gandhārī word pavaj- or Pāli pabbajas etymologically connected to $\mathrm{papa}^{25}$

In addition, there is a notable case found in the Fo kaijie fanzhiaba jing 佛開解㷊志阿威 經 (T. 20), which is traditionally attributed to Zhi Qian but not included in the list of his genuine works prepared by Nattier (2008b, pp. 177-78; 2019, p. 821). In this sūtra, the term shezui 捨罪 is used in the sense of pravraj- as follows:

T. 20, 264a13-16: 阿風等五百人，(a)欲作沙門，佛言: 各自歸家，善持五戒，意志已 固, (b)乃可捨罪”。佛説經已, 皆大歡喜, 作禮而去。 [Var.: 自=且 (三); ${ }^{*}$ 罪=家 (三); 而=如 (三)]

Ambāștha and five hundred people desired to be ordained (lit. become śramanas). The Buddha said "Each [of you should] go home and keep the five precepts well. [When you are] firm in resolve, then [you] may be ordained." When the Buddha spoke [thus], all of them rejoiced. Having made obeisance, they left.

After the expression (a) yu zuo shamen 欲作沙門, “to desire to become a monk", it seems reasonable to interpret the following phrase (b) nai ke shezui 乃可捨罪 as “then, [one] may become a monk" and not as "then [one] may abandon sins." The Taishō edition as well as the second Koryŏ edition on which the Taishō edition is based contain the term shezui 捨 罪, whereas the Sixi zang 思溪藏 (1126-1138), the Puning zang 普寧藏 (1277-1290), and the Jingshan zang 徑山藏 (1589-1712) read shejia 捨家 (abandon home) as indicated in the Taishō note (see above). Thus, the correct, or rather original, reading here is presumably shezui 捨 罪, as presented in the second Koryŏ edition, even though the term shejia 捨家 sounds more natural in the given context. It is also likely that this modification was made by the editor(s), who did not know that the term shezui referred to pravraj-in Zhi Qian's terminology or who thought that the term does not adequately convey the original meaning of the text. Further, although this occurrence of a single term, shezui, is limited evidence, it may support the supposition that the Fo kaijie fanzhiaba jing is Zhi Qian's genuine work or a text related to him. ${ }^{26}$

\subsection{Kong 空, Wu Xiang 無想, and Bu Yuan 不願: Emptiness, Signlessness, and Wishlessness}

The word kong 空 is a good example of the Buddhist influence on Chinese terminologies, particularly in terms of their semantic changes. It used to simply mean "hollow" or "nothing", similar to $w u$ 無, but its meaning was later extended to reflect the concept of śūnyatā with much greater philosophical depth. ${ }^{27}$ Even as late as the Dang dynasty, we find, parallel with the Buddhist connotation, what sems to be the original meaning of the word kong, where the term sikong 司空 is used for a title of Amoghavajra (Bukong 不空, 704-774), meaning "Imperial craftsman" or "Imperial architect" (cf. Hucker 1985, p. 450, nr. 5687). The fact that the word is originally associated with craftmanship is also evident in the etymology of the character kong 空. ${ }^{28}$ The character kong may be a phonetic loan to represent the concept of "empty", but the old Sino-Tibetan words kong, etc., seem also to connote "boring a hole", etc., as documented, e.g., in Naxi, Tamang, and Western Tani, underpinning the meaning expressed by the character. ${ }^{29}$

In pre-Buddhist Chinese, the two characters xiang 想, usually equivalent to samjiñ $\bar{a}$, and xiang相, most often used to represent nimitta, have often been used in the same sense from the very early period of Chinese Buddhist translation (cf. Karashima 1998, pp. 474- 
75; Karashima 2010, pp. 517-18; Vetter 2012, pp. 116, 210-11). Rather, the two terms represent a case of semantic continuity, as xiang想 would in early texts mostly mean “to perceive, conceptualise", while xiang相 would carry the connotation of "mutually, each other, meeting with" but also "to see, to perceive". The classical terms were thus the natural choices for the early translators, though xiang 相 would absorb the special Buddhist meaning of "quality, distinguishing mark (in perception)," that is, nimitta, as a technical term. The terms samjiñ $\bar{a}$ and nimitta are also interrelated in Buddhist epistemological theory—samjiñā being defined as nimittagraha (cf., e.g., samjīñ nimittodgrahanātmikā in the Abhidharmakośa 1.14 (Pradhan 1967, p. 10)). The two xiangs are, though, often intermingled in Chinese translations, at least as we have them handed down.

The etymological connotations of pranidhi and pranidhāna would be "place at, in, before" and in the Buddhist use, evidently to "place your mind" at "some object". Thus, in the Mahāyāna context, the word acquires the meaning of "wish" but with both positive and negative connotations. First, it denotes the bodhisattva's wish or promise to attain bodhi, more or less a synonym of bodhicitta. In the other use, as is relevant here in the case of trīni vimokșamukhāni (three doors to liberation), the pranidhāna still means wish but refers to wishful thinking to be done away with, similar to that of constructing qualities (nimitta) of objects and then wanting them, though they are of course empty, constructed, and illusory. The meaning of yuan 願 before it was "invaded" by the special and well-defined connotations of Buddhism, is gleaned from a number of classical texts as "to long for (often persons)" but also “deep desire" in general. In this way, the case of yuan 原 is that of semantic continuity but is recreated as (two!) Buddhist technical terms; yuan 原 acquires a much more defined philosophical and religious connotation when adopted by Lokakṣema, Zhi Qian, and the other translators.

The words kong 空, wu xiang 無想, and bu yuan 不願are Zhi Qian's translations, often in a set of three (空無想不原) for śūnyata (emptiness), animitta (signlessness), and apranihita (wishlessness), which represent the three doors to liberation (trīni vimoksamukhāni). According to Zacchetti (2008, p. 472), this string of three words, particularly the term bu yuan, is rare, mostly only occurring in the texts dating back to the Three Kingdoms period. Indeed, the Parthian An Shigao, who is the first historical figure of Chinese Buddhism active in Luoyang (洛陽) during the Later Han dynasty, uses kong 空, bu xiang 不想, and bu yuan 不 原 for śünyatā, animitta, and apranihita (Vetter 2012, p. 224). Soon afterwards, however, the terms bu xiang 不想 and bu yuan不願 seem to have been replaced by wu xiang 無想 and wu yuan無原, as can be seen in the works of Lokakṣema and Dharmarakșa (Karashima 1998, pp. 475-76; Karashima 2010, pp. 521-22), and wu xiang and wu yuan are now generally accepted for animitta and apranihita (cf. DDB, s.v. 無相, 無願, 空無相無原). In this regard, it is notable that Zhi Qian, who was later than Lokakșema, still used bu yuan for apranihita, but adopted wu xiang for animitta at the same time. The set of words kong, wu xiang, and bu yuan is found only once in the Benye jing but more often in Zhi Qian's other works. ${ }^{30}$ For instance, it occurs five times in the Da mingdu jing (T. 225, 478c3, 478c11, 479a7-8, 496c8, and 505b27), ${ }^{31}$ twice in the Foshuo weimojie jing (T. 474, 526b18-19 and 526b21), and once each in the Fanmoyu jing 梵摩渝經 (T. 76, 884b17) and the Faju jing (T. 210, 561b13). Let us look at the following sentences that include this set of words:

Zhi Qian (T. 281, 447b12-13): (a) 言見信用, (b) 降心正意, (c) 攝念入樿, (d) 憢空、 無想、不䫧之法. [Var.: 想不=相無 (三、宮、聖乙)]

[How should he practice] (a) to make his word trustworthy? [How should he practice] (b) to control himself [for the sake of] correct thought, (c) to keep his mind in concentration, and (d) to comprehend the emptiness, signlessness, and wishlessness?

Lokakșema (T. 280, 451a25-28): (a) 多所出入語者，人皆信用之，無有不敬附者; 身 所行無有不淨潔者; 諸所視經無有不了知者。(b) 一心降意, (d) 思惟明曉, (c) 迴念 入禪。[Var.: 降=隆 (森、宮); 迴=佪 (三、宮)] 
(a) The words that he often recited can all be trusted by people, so there is no one who does not respect or follow him. The action produced by his body is nothing but pure; regarding all sūtras that he looked into, there was nothing left to understand. (b) He one-pointedly controlled his mind, (d) contemplated the enlightenment, and (c) was attentive in entering into meditation.

Tib. (D185, 211b1): ... ston pa ñid yon்s su bsgoms pa yin I mtshan ma med pa yon்s su bsgoms pa yin I smon pa med pa yons su bsgoms pa yin ...

... he has been thoroughly imbued with [the notions of] emptiness, signlessness, and wishlessness ...

Here, even though Zhi Qian's translation does not completely agree with Lokakșema's, the two Chinese versions seem related to one another to some extent. That is to say, (a) yanjian xinyong 言見信用, (b) jiangxin zhengyi 降心正意, and (c) shenian ruchan 攝念入樿 in T. 280 correspond to the (a) duosuo churu yuzhe, ren jie xinyong zhi 多所出入語者，人皆信用 之, (b) yixin jiangyi 一心降意, and (c) shenian ruchan 攝念入禪 in T. 281, respectively. There is, however, no counterpart for the terms (d) kong 空, wu xiang 無想, and bu yuan 不願 in Lokakșema's translation, apart from the word xiao 鹰 in the phrase siwei mingxiao 思惟明 墝 (to be awakened to what he thinks). Thus, it seems safe to say that a counterpart of the expression, kong, wu xiang, and bu yuan, is only found in the Tibetan translation and not in Lokakșema's translation. Since the Tibetan translation has the corresponding set of words, ston pa ñid, mtshan ma med pa, and smon pa med pa, and since it is impossible to derive the concepts kong, wu xiang, and bu yuan without referring to sources other than Lokaksema's translation, it is likely that Zhi Qian had access to an Indic original, although we do not know what version it was. We can also assume that, when Zhi Qian worked on the Benye jing, he not only consulted an already existing translation as we will see below, but he also consulted, at least to some degree, the Indic original.

\subsection{Sishi Buhu 四時不護: Four Methods of Winning [People] Over}

Finally, we will present an additional terminological issue found in the Benye jing in the Taishō edition. The phrase sishi buhu 四時不護, which literally means “four periods of non-guards", is found nowhere else in the entire Taishō edition. No variant reading is given in the Taishō edition. However, this expression appears as sishi buhu 四事不護 (four kinds of non-guards) in the corresponding passage in the second Koryo 高麗 edition (13th century CE) as well as in all other ancient printed editions available to us, namely the Qisha zang 磧砂藏 (completed in 1322), the Hongwu nan zang 洪武南藏 (completed in 1402), and the Qing zang 清藏 (completed in 1738). ${ }^{32}$ Furthermore, another important modern edition, the Zhonghua dazangjing 中華大藏經, has the same phrase, sishi buhu, in the corresponding place without indicating any variant readings. Therefore, the same reading is probably found in all of the editions collated in the Zhonghua dazangjing, namely the Sixi 思溪 edition (completed in 1138), the Puning zang 普寧藏 (completed in 1290), the Yongle nan zang 永樂 南藏 (completed in 1420), and the Jingshan zang 徑山藏 (completed in 1712). ${ }^{33}$ More notably, the phrase sishi bu hu 四事不護 is found in a parallel passage in the Foshuo dousha jing 佛晲 沙經 (T. 280):

Zhi Qian (T. 281, 446c14-16): 悉爲我現佛行、佛智、佛神、佛力、佛定、無量變 化隨時。四時不護、四無所畏、十八不絶、一切敏慧、無上道徳, 衆事敷露。

He shows us the Buddha's practice, the Buddha's knowledge, the Buddha's supernormal power, the Buddha's ability, the Buddha's samādhi, and (the Buddha's) immeasurable transformation as the situation demands. He also presents all qualities [of the Buddha, namely], the four kinds of non-guards, the four forms of fearlessness, the eighteen distinctive abilities, all kinds of wisdom, and the utmost merit.

Lokakssema (T. 283, 445b8-15): 現我佛所止處, 現我佛諸法所部界, 現我佛威神，現 我佛所行，現我佛筋力，現我佛四事不護，現我佛三昧所入處，現我佛所變化在所 
爲, 現我佛無有過勝者, 現我佛所有尊號, 無有能及逮者, 現我佛所根, 現我佛飛, 現 我佛光明, 現我佛智慧, 現我佛四事無所畏。佛悉知諸菩薩心所念, 佛悉現光明威 神。

He shows us the place where the Buddha dwells; he shows us the field and boundary of all the Buddha's dharmas; he shows us the Buddha's dignity; he shows us the Buddha's practice; he shows us the Buddha's power; he shows us the Buddha's four kinds of non-guards; he shows us the place where the Buddha entered into for samādhi; he shows us the Buddha's transformations taking place where needed; he shows us that no one transcends the Buddha; he shows that the respected names that are possessed by the Buddha; [he shows us that] no one reaches [the Buddha]; he shows where the Buddha originated from; he shows the Buddha's high [stature]; he shows the Buddha's brightness; he shows us the Buddha's wisdom; and he shows the Buddha's four forms of fearlessness. The Buddha knows completely what all bodhisattvas thinks and completely shows his brightness and dignity.

Two inferences can be made from these passages:

(1) It is very probable that the phrase sishi buhu 四時不護 in the Benye jing in the Taishō edition is not a misinterpretation but an editorial error for the phrase sishi buhu 四事不護. It is likely that the error was the result of confusing the characters shi 事 and shi 時 (perhaps influenced by the compound suishi 隨時, underlined in the previous phrase), even though the words are pronounced in different tones. This case is a good example that highlights the importance of directly consulting multiple editions in the study of Chinese Buddhist texts and not just relying on the given apparatus. ${ }^{34}$

(2) According to Karashima, the phrase sishi buhu 四事不護 is Lokakșema's misinterpretation of catursamgrahavastu (four means of attracting people) (Karashima 2011, p. 464), which is more often translated as si shefa 四攝法 (four methods of winning (people) over). Since there is no counterpart in the corresponding passage in the Tibetan Buddhāvatamsaka (D44, 176b2-7), it can be assumed that Zhi Qian directly consulted Lokaksema's translation here, which is now known as the Foshuo dousha jing, and that he borrowed the expression sishi bu hu 四事不護 from there even though it was initially misinterpreted. Indeed, it is difficult to explain why Lokakṣema translated samgraha, which means "seizing, grasping" as buhu 不護 (not guarding, not being on guard), ${ }^{35}$ and why Zhi Qian subsequently adopted this translation without modification. ${ }^{36}$ This is an example of how investigating a mistranslation may lead to further topics of discussion: in this case, the textual relationship between the Benye jing and the Foshuo dousha jing and Zhi Qian's translation procedure.

\section{Conclusions}

This paper is a follow-up to the authors' previous study (Han et al. 2021) dealing with Zhi Qian's stylistic embellishments in the Foshuo pusa benye jing (佛菩薩本業經, T. 281). Zhi Qian played a significant role in the introduction and spread of Buddhism in China during the Three Kingdoms period (ca. 220-280 CE), and the Benye jing, one of his most influential pieces among his works, clearly documents his unique translation style and techniques. ${ }^{37}$ In the present paper, we examined Zhi Qian's four particular renderings in the Benye jing, viz., (1) santu 三塗, (2) shezui 捨罪, (3) kong 空, wu xiang 無想 and bu yuan 不 原, and (4) sishi buhu 四時不護, and discussed their semantic interpretations and their later reception in the history of Chinese Buddhist translation. Specifically, it was shown that the terms santu 三塗and shezui 捨罪 are Zhi Qian's unique renderings of tryadhvan (the three times) and pravraj- (to become a monk), respectively, and that the two cases are examples of Zhi Qian's lexical idiosyncrasies that may shed further light on the questions of how to identify his genuine works. The set of words kong 空, wu xiang 無想, and bu yuan 不原 allowed us to see the dynamic process of language change, or rather evolution, during the formative period of Chinese Buddhism, and Zhi Qian's place therein. The term sishi buhu 四時不護, probably an editorial error only occurring in the Taishō edition, demonstrated 
the necessity of consulting multiple editions in the study of Chinese Buddhist texts. The last two cases, kong, wu xiang, bu yuan, and sishi buhu, also showed how the Benye jing was produced, that is, through the use of an Indic original source but also with reference to Lokakșema's pre-existing translation.

In this paper, we also illustrated some semantic changes of the Chinese language taking place in the period as well as the influence of Buddhist regimes of knowledge. The semantic continuities, or disruptions, between classical Chinese and Buddhist Chinese seem to be quite understudied though the topic potentially has great importance for understanding the Chinese history of language as well as the history of Chinese thought. In view of this, as the authors of this paper, we would contend that the semantic changes of the Chinese language deserve further study.

Author Contributions: Writing-original draft, J.H.; Supervision, S.H.; writing-review and editing, H.L.; writing-review and editing, J.B. All authors have read and agreed to the published version of the manuscript.

Funding: This research received no external funding.

Institutional Review Board Statement: Not applicable.

Informed Consent Statement: Not applicable.

Data Availability Statement: Not applicable.

Acknowledgments: We wish to thank Ven. Chongdok, Ven. Jianrong, Robert Kritzer, Kyungrae Kim, and Fredrik Liland for their helpful advice and valuable suggestions on earlier drafts of this paper. We also thank the two anonymous reviewers for their careful reading of the manuscript and their constructive comments. Any remaining errors are our own.

Conflicts of Interest: The authors declare no conflict of interest.

\author{
Abbreviations \\ BHSD Buddhist Hybrid Sanskrit Dictionary by Franklin Edgerton. Available online: \\ https: / / gandhari.org/dictionary?section=bhsd (accessed on 5 June 2021) \\ D Derge Kanjur (Karmapa edition 1976-1979). Available online: \\ https:/ / www.tbrc.org/\#!footer/about/newhome (accessed on 5 June 2021) \\ DhpBHS Buddhist Hybrid Sanskrit Dharmapada (Shukla, Narayan S. 1979. The Buddhist \\ Hybrid Sanskrit Dharmapada. Patna: K. P. Jayaswal Research Institute). \\ DhpChi Faju jing 法句經 (Chinese translation of Dhammapada, T.210). \\ DhpG. Gāndhārī Dharmapada (Brough, John. 1962. The Gāndhārī Dharmapada: Edited with \\ an Introduction and Commentary, Oxford University Press, London). \\ DhpP. Pāli Dhammapada (Khuddaka Nikāya text No. 2, Sutta Pițaka, PTS) \\ G. Gāndhārī \\ GD A Dictionary of Gāndhārī by Stefan Baums and Andrew Glass. Available online: \\ Available online: https:/ / gandhari.org/1a (accessed on 5 June 2021) \\ MW A Sanskrit-English Dictionary by Monier Monier-Williams. Available online: \\ https: / / gandhari.org/dictionary?section=mw (accessed on 5 June 2021) \\ P. Pāli \\ Skt. Sanskrit \\ T. Taishō shinshū daizōkyō 大正新脩大藏經. Available online: \\ https:/ /21dzk.1.u-tokyo.ac.jp/SAT2012/index.html (accessed on 5 June 2021) \\ Tib. Tibetan \\ UvSkt Sanskrit Udānavarga (Bernhard, Franz. 1965. Udānavarga. Göttingen: Vandenhoeck \\ and Ruprecht). \\ UvTib Ched du brjod pa'i tshoms (Tibetan translation of Udānavarga, Kg mdo sde sa, 209a1-253a7). \\ VknSkt Sanskrit Vimalakīrtinirdeśa (see SGBSL 2004). \\ VknTib 'Phags pa dri ma med par grags pas bstan pa (Tibetan translation of Vimalakīrtinirdeśa, \\ Kg. D176 mdo sde, ma 175a1-239b7, vol. 60)
}




\section{Notes}

1 For the spread of Buddhist thought in China, see (Braarvig 2012). On Chinese lexicography and on language diffusion and dominant/dependent languages in general, see (Braarvig 2018b, 2018a), respectively.

2 The term "sinicisation" as used here is concerned with the early Chinese Buddhist translators' various attempts to produce more readable translations for the readers of Chinese during the Eastern Han dynasty and early Weijin period. For the meaning and context of the term "sinicisation" used in our study, see (Han et al. 2021, pp. 11-12n6).

3 Notably, a critical reading of the Benye jing reveals its similarity to the poetic prose $f u$ 賦 of classical Chinese literature. Fu, which is generally translated as "rhapsody", "epic poem", or "poetic exposition", was the dominant literary genre of the Han dynasty, mainly composed and recited at the imperial courts or among the cultured people of the time. According to Knechtges, it can be characterised as "a mixture of prose and verse, relatively long lines, parallelism, elaborate description, dialogue, extensive cataloging, and difficult language" (Knechtges 1976, p. 13). Indeed, the Benye jing represents itself as a highly polished piece of Buddhist literature, in which one can easily find such characteristics, most notably, the insertion of verse into a prose structure, which is one of the distinguishing formal features of the $f u$. We plan to investigate this point further in a future publication. On the historical importance and literary characteristics of the Chinese literary form, $f u$, in the context of classical Chinese literature, see (Knechtges 1976; Kern 2003).

4 However, the other terminologies of the earlier translations were also learned creations and as such, were very far from vernacular and colloquial language, under which category they have sometimes been subsumed by sinological scholarship, notwithstanding the bisyllabic nature of Buddhist terms. The reason for the bisyllabic terms was probably a means to catch the Buddhist semantics that were foreign to the Chinese conceptual world at the time, where the monosyllabic classical language could not cope with novel concepts without modifications.

5 According to the Zhiyuan fabao kantong zonglu 至元法寶堪同總, a comparative Sino-Tibetan catalogue compiled by Qing Jixiang 慶吉祥 in the late 13th century, the Tibetan Buddhāvatamsaka was translated from the Chinese translation. Yet, recent studies have shown that it was not based on the Chinese version but on the Sanskrit original. For more details on the textual history of the Tibetan Buddhāvatamsaka, see (Hamar 2007, pp. 165-67).

6 However, the word shi 時 for Skt. samaya, etc., (e.g., ekasmin samaye ...) is retained in Buddhism but is never used for the Buddhist abstract concept of time and rather denotes a day or a point of time.

7 Henceforth, Indic words are Sanskrit unless otherwise specified.

8 On the use of the term adhvan in the Buddhist context and its etymological background, see (Fussman 1974, p. 55; Strauch 2009, p. 211 and p. 217n5-6). For a discussion of Patañjali's use of this term with reference to the time in his Yogasūtra and its relations to Sarvāstivāda Buddhist doctrine, see (Maas 2020, p. 987).

9 Zürcher mentions the term san tu 三塗in his study on the Buddhist influence on early Daoist notions and terminology, but he treats it in the context of the three evil destinations not as the three times. See (Zürcher [1980] 2013, p. 137).

10 All citations in this article from the Taishō edition have been re-punctuated by the authors, based on their reading of the texts.

11 It is questionable whether the word san shi 三世 was used by Lokakșema. According to Nattier (2008b, p. 176), two texts, the Daoxing banruo jing 道行般若經 (T. 224) and the unrevised prose potion of the Banzhou sanmei jing 般舟三昧經 (T. 418), are identified as Lokakșema's core texts, while the other texts attributed to him are probably related to his circle and not to Lokakșema himself. The term tryadhvan occurs three times in the Aștasāhasrikā Prajñāpāramitā (Vaidya 1960, pp. 75, 95), but there is no counterpart in the corresponding parts of the Daoxing banruo jing, the Lokakșema's translation of the Aștasāhasrikā Prajñāāaramitā (Karashima 2011, pp. 145n14, 183). Furthermore, the term san shi 三世 is found only once in the verse potion of the Banzhou sanmei jing (T. 418, 911c28) and in the Pusa shizhu xingdao pin (T. 283, 455b11), both texts that may have been revised or refined by his circle.

12 There is no counterpart for T. 281, 450c4 and T. 282, 456a25-26 in the Tibetan version.

13 Some examples follow: (1) 陪臣執國命, 三世希不失矣。“When the subsidiary ministers of the great officers hold in their grasp the orders of the state, as a rule the cases will be few in which they do not lose their power in three generations" (Lunyu 論語/ Jishi 季氏/ 2, ICS Lunyu: 16.2/45/26, tr. James Legge). (2) 去國三世，爵淥有列於朝，出入有詔於國，若兄弟宗族猶存，則反告於宗 後。“(But) if he (or his descendants) has been away from the state for three generations, and if his dignity and emoluments be (still) reckoned to him (or his representative) at the court, and his outgoings and incomings are announced to the state, and if his brothers or cousins and other members of his house be still there, he should (continue to) send back word about himself to the representative of his ancestor. (Even) after the three generations, if his dignity and emoluments be not reckoned to him in the court, and his outgoings and incomings are (no longer) announced in the state, it is only on the day of his elevation (to official rank) that he should follow the ways of his new state" (Liji 禮記/曲禮下 Quli II/ 85, tr. James Legge). (3) 越人三世其 君，王子搜患之，逃乎丹穴。“The people of Yue *three times in succession killed their ruler, and the prince Sou, distressed by it, made his escape to the caves of Dan" (Zhuangzi 莊子/ Rangwang 讓王/ 3, ICS Zhuangzi: 28/82/1, Harvard-Yenching Zhuangzi Yinde: $77 / 28 / 15$, tr. James Legge). *The underlined san shi 三世 should be translated as "three generations" not as "three times". Legge's translation is incorrect. (4) 今王發明惠, 諸侯之士來歸義者, 今使復之三世, 無知軍事。“Now, if Your Majesty will issue a favourable proclamation to the effect that those soldiers of the various feudal lords who will come and submit, will be granted 
exemption for three generations, without hearing anything of military affairs" (Shangjun Shu 商君書/Laimin 來民/ 4, ICS Shangjunshu: 15/20/1, tr. J. J. L. Duyvendak). For more references, cf. Chinese Text Project (https://ctext.org) s.v. 三世 (accessed on 1 June 2021).

For a detailed discussion of the concept of time in Indian context, see (Balslev 1983).

The term occurs once more in the latter part (Chapter 7) of the Da mingdu jing (T. 225, 488a9), but it is not related to this argument since it refers to "the three evil destinies," which is a more frequent usage of the term san tu 三塗.

Skt. sarvākārajñatācaryā prathamah parivartah (Chapter 1: Practice of the knowledge of all aspects).

See (Karashima 2006, p. 363; Karashima 2016; Nattier 2007a, pp. 115-17 (particularly footnotes 23-25); Nattier 2008c, pp. 108-9). T. 281，447a25-447b1: 忉利天、炎天、樂術天、不憍樂天、化應聲天、梵天、梵衆天、梵輔天、大梵天、清明天、水行 天、水微天、水無量天、水音天、約淨天、遍淨天、淨明天、守妙天、微妙天、廣妙天、極妙天、福愛天、愛勝天、近際天、 善觀天、快見天、無結愛天、識慧天、無所念慧天。[Var.: 炎=鹽 (三、宮、聖Z)]

Nattier suggests veda for the reconstruction of the original word derived from vid- (Nattier 2007a, pp. 116-17). The sound change from G. $-d$ - to Skt. $-y$ - is common since both are palatals. OIA - $e$ - is also changeable to - $i-$ in M, AMg, JM. Cf. (Pischel 1981, p. 90). For the last three examples, see T. 281, 446c17-447a6:

東去無極 有香林刹 佛名入精進 菩薩字敬首

南去無極 有樂林刹 佛名不捨樂 菩薩字覺首

西去無極 有華林刹 佛名習精進 菩薩字寶首 $\ldots$.

上方無極 有欲林刹 佛名至精進 菩薩字賢首 [Var.: 樂=樂精進 (三、宮、聖Z)]

For the attribution of the Faju jing 法句經 (T. 210) and the process of its translation, see Zhi Qian's Faju Jing Xu 法句䋑序，“Preface to the Translation of the Dharmapāda" see (Cheung and Lin 2006, pp. 58-63).

All translations in this article are by the authors.

The palatal plosive $j(f)$ is weakened to $y$ (j) when surrounded by vowels (Baums [2010] 2019, p. 4).

The term chujia 出家 is a new expression imported into the Chinese language through the influence of Buddhism (Guang 2012, p. 160).

That such hermeneutics are employed as very conscious processes when translating Buddhist litarature into Chinese, and, indeed, into Tibetan, is well documented in Chinese and Tibetan biingual lexicography (Braarvig 2018b). See also (Braarvig et al. 2017) for an example of Indian monolingual synonym lexicography and (Kahrs 1998) for the Indian tradition of etymological analysis. Park, too, suggests in his posthumous work that the Fo kaijie fanzhiaba jing may be a genuine translation of Zhi Qian (Park 2012, pp. 28-36), but his argument is not widely accepted by other scholars (see, for an example, Nattier 2019).

For more discussion of such semantic development in the Chinese lexicon, including the term kong 空, see (Sun 2006; Guang 2012).

Perhaps it referred to the holes drilled by craftsmen or to the spaces created inside houses. Compare this character with xue 穴 (cave, hole) for meaning and kong I (tool, craft) for pronunciation.

Cf. Sino-Tibetan Etymological Dictionary and Thesaurus (STEDT: https://stedt.berkeley.edu/ stedt-cgi/rootcanal.pl/etymon/ 820) (accessed on 29 June 2021).

On Zhi Qian's authentic translations, see (Nattier 2008b, pp. 177-78; 2019, pp. 820-21).

However, the following two points should be noted. First, the order of the three words is different, viz. 空一不願一無想. Second, the first three occurrences are found in the first chapter of the Da mingdu jing, which is not considered to be Zhi Qian's genuine work by modern Buddhist scholars, such as Lancaster, Karashima, and Nattier. This is because regarding wording and sentence style, the Da mingdu jing can be divided into two parts: (1) from the beginning to the end of Chapter 1, including the interlinear commentary and the use of unusual vocabulary with an irregular prosodic style that appears not to be ascribed to Zhi Qian; (2) the remainder of the sütra, Chapters 2-27, written in elegant four-character prosody without interlinear commentary, which is considered to be Zhi Qian's authentic translation. For more discussion on the attribution of the Da mingdu jing, see (Lancaster 1969; Katsuzaki 1985; Nattier 2008a).

32 The references are as follows: (1) for the second Koryŏ edition (Jaejo taejanggyong 再雕大藏綬), K94v8, p. 1115a21 (available online: http:/ / abchome.dongguk.edu) (accessed on 21 December 2020); (2) for the Qisha zang, see the Song ban Qisha dazangjing 宋板磧砂 大藏經 (台北: 新文豊出版公司 1987), vol. 8, pp. 339-42; (3) for the Hongwu nan zang, see the Hongwu nan zang 洪武南藏 (成都: 四 川省佛協會 1999), vol. 40, pp. 309-22; (4) for the Qing zang, see the Long zang 龍藏 (台北: 華藏淨宗學會 2005), vol. 28, pp. 228-38. Cf. Zhonghua dazangjing 中華大藏經 (北京: 中國藏學出版社 [1984-1988] 2008), vol. 13. 667-77. Unfortunately, the Benye jing is not included in the Fangshan shijing 房山石經 or the Zhaocheng jin zang 趙城金藏, both regarded as important witnesses for the understanding of the textual transmission of the Chinese Buddhist canons.

The second Koryŏ edition may be a feasible option for additional textual witnesses since it is fully digitalised and made accessible online (digital photos and e-text available from the Academy of Buddhist Studies at Dongguk University: http: / / abchome.dongguk.edu) (accessed on 31 May 2021). Additionally, the Zhonghua dazangjing, compiled in Beijing between 1984 and 1988, seems to be a good option, as it contains critical apparatuses from various pre-modern editions at the end of each $j u a n$ 
卷. However, it should be noted that the reliability of the apparatus is not completely guaranteed. For more discussion of the Dazangjing Studies from a textual critical perspective, including the history of various editions and relationships among them, see (Zacchetti 2005, pp. 74-140).

35 The term si shi 四事 probably corresponds to Skt. catur... vastu.

36 It should also be noted that Zhi Qian uses a different term, si en 四恩 (four kinds of kindness), in his translation of the Vimalakìtinirdeśa (T. 474, 520b3, 524b5-6). This appears to be a more appropriate rendering for catursamgrahavastu. Here, the parallels in Sanskrit, Tibetan, and Chinese are as follows:

(a) VknSkt. 6a7: catvāri saṃgrahavastūni kulaputra bodhisattvasya buddhakṣetram, tasya bodhiprāptasya sarvavimuktisaṃgrhītāh satvā buddhakṣetre saṃhavanti I

VknTib. 179b3: bsdu ba'i dn்os po bźi rnams ni byan் chub sems dpa'i sañs royas kyi żin ste l de byan chub thob pa'i sañs royas kyi żin der rnam par grol ba thams cad kyis yon்s su zin pa'i sems can rnams skye bar 'gyur ro I I

Zhi Qian T. 474, 520b3: 菩薩行四恩為國故，於佛國得道，惠施仁愛利人等利，一切救濟 合聚人民生於佛土。[Var.: 於=于 (三)]Kumārajīva T.475 538b14-15: 菩薩成佛時, 成就慈悲喜唅䍙生來生其國。四攝法是菩薩淨土。菩薩成佛時, 解所攝䍙生來生其 國。

Xuanzang T.476 559b23-25: 四無量土 是為菩薩嚴淨佛土。菩薩證得大菩提時, 常住慈悲喜捨有情來生其國。

Note: Kumārajīiva translates catursamgrahavastu as si shefa 四攝法 (four means of conversion), which is the most frequently used Chinese term for it, whereas Xuanzang uses si wuliang 四無量, which corresponds to catvāryapramānāni (four immeasurables). (See the underlined portions.) It is far from clear whether Xuanzang's different or inaccurate translation here results from a misinterpretation of the same text as ion or from the use of a different source.

(b) VknSkt 22b1: samgrahavastumanda eșa sarvasatvasamgrahanatayā I

VknTib. 193b6: sems can thams cad sdud pa'i phyir de ni bsdu pa'i dinos po'i sñin po'o । ।

Zhi Qian T. 474 524b5-6: 四思之心是, 合聚人故。[Var.: 思=恩 (三)]Kumārajīva T. 475 542c24-25: 四攝是道場攝䍙生故.

Xuanzang T. 476 565b27-28: 攝事是妙菩提, 攝諸有情故.

Note: The underlined term sisi 四思 in T. 474 appears to be an editorial error for sien 四恩, as in the case of sishi buhu 四時不 護, given the context as well as the variant reading.

37 On the Benye jing and its historical significance in the development of Chinese Buddhism as well as of early Daoist philosophy see also (Bokenkamp 1983, 1990; Nattier 2007a).

\section{References}

Balslev, Anindita Niyogi. 1983. A Study of Time in Indian Philosophy. Wiesbaden: Otto Harrassoitz.

Baums, Stefan. 2019. Outline of Gāndhārī Grammar. Available online: https://stefanbaums.com/baums_grammar_outline.pdf (accessed on 1 June 2021). First published 2010.

Bokenkamp, Stephen R. 1983. Sources of the Ling-pao Scriptures. In Tantric and Taoist Studies in Honour of R. A. Stien. Edited by Michel Strickmann. Brussels: Institut Belge des Hautes Études Chinoises, pp. 434-86.

Bokenkamp, Stephen R. 1990. Stages of Transcendence: The Bhumi Concept in Taoist Scripture Glossary of Chinese Terms. In Chinese Buddhist Apocrypha. Edited by Robert E. Buswell. Honolulu: University of Hawaii Press, pp. 119-47.

Braarvig, Jens. 2012. The spread of Buddhism as globalization of knowledge. In The Globalization of Knowledge in History. Edited by Jürgen Renn. Berlin: Max Planck Institute for the History of Science, pp. 245-67. Available online: https://www.mprl-series.mpg. de/studies/1/ (accessed on 23 June 2021).

Braarvig, Jens. 2018a. Dependent Languages. In Multilingualism, Lingua Franca and Lingua Sacra. Edited by Jens Braarvig and Markham J. Geller. Berlin: Max Planck Institute for the History of Science, pp. 79-90. Available online: https://www.mprl-series.mpg.de/ studies/10/index.html (accessed on 23 June 2021).

Braarvig, Jens. 2018b. The Imprint of Buddhist Sanskrit on Chinese and Tibetan: Some Lexical Ontologies and Translation Strategies in the Tang Dynasty. In Multilingualism, Lingua Franca and Lingua Sacra. Edited by Jens Braarvig and Markham J. Geller. Berlin: Max Planck Institute for the History of Science, pp. 427-50.

Braarvig, Jens, Han Jaehee, Lee Hyebin, and Leuritthikul Weerachai. 2017. A Synonym Lexicon Similar to the Amarakosa. Tokyo: The International Research Institute for Advanced Buddhology, Soka University, vol. 21, pp. 309-13.

Cheung, Martha, and Wusun Lin. 2006. An Anthology of Chinese Discourse on Translation: Vol. 1: From Earliest Times to the Buddhist Project. Manchester: St. Jerome Publisher.

Coblin, W. South. 1983. A handbook of Eastern Han Sound Glosses. Hong Kong: Chinese University Press.

Feng, Zhiwei. 2004. The Semantic Loanwords and Phonemic Loanwords in Chinese Language. In Aspects of Foreign Words/Loanwords in the Word's Language: Proceedings for 11th International Symposium. Tokyo: The National Institute for Japanese Language, pp. 200-29.

Fussman, Gérard. 1974. Documents épigraphiques kouchans. Bulletin de l'Ecole française d'Extrême-Orient 61: 1-76. [CrossRef]

Guang, Xing. 2012. Buddhist Impact on Chinese Language. Journal of the Centre for Buddhist Studies 10: 155-76.

Hamar, Imre. 2007. The History of the Buddhāvatamsaka-sūtra: Shorter and Larger Texts. In Reflecting Mirrors: Perspectives on Huayan Buddhism. Edited by Imre Hamar. Wiesbaden: Harrassowitz Verlag, pp. 139-67.

Han, Jaehee, Hwang Soonil, and Lee Hyebin. 2021. "Buddhism for Chinese Readers": Zhi Qian's Literary Refinements in the Foshuo pusa benye jing. Religions 12: 361. [CrossRef] 
Hucker, Charles O. 1985. A Dictionary of Official Titles in Imperial China. Stanford: Stanford University Press.

Kahrs, Eivind. 1998. Indian Semantic Analysis: The Nirvacana Tradition. Cambridge: Cambridge University Press.

Karashima, Seishi. 1992. The Textual Study of the Chinese Versions of the Saddharmapundarikasutra: In the Light of the Sanskrit and Tibetan Versions. Tokyo: Sankibo Press.

Karashima, Seishi. 1998. A Glossary of Dharmaraksa's Translation of the Lotus Sutra. Tokyo: The International Research Institute for Advanced Buddhology, Soka University.

Karashima, Seishi. 2001. Some Features of the Language of the Saddharmapundarīkasūtra. Indo-Iranian Journal 44: 207-30. [CrossRef]

Karashima, Seishi. 2006. Underlying Languages of Early Chinese Translations of Buddhist Scriptures. In Studies in Chinese Language and Culture: Festschrift in Honour of Christoph Harbsmeier on the Occasion of His 60th Birthday. Edited by Christoph Anderl and Halvor Eifring. Oslo: Hermes Academic Publishing, pp. 355-66.

Karashima, Seishi. 2010. A Glossary of Lokaksema's Translation of the Astasahasrika Prajnaparamita. Tokyo: The International Research Institute for Advanced Buddhology, Soka University.

Karashima, Seishi. 2011. A Critical Edition of Lokakșema's Translation of the Aștasāhasrikā Prajñāprāmitā. Tokyo: The International Research Institute for Advanced Buddhology, Soka University.

Karashima, Seishi. 2013a. Was the Aștasāhasrikā Prajūāpāramitā Compiled in Gandhāra in Gāndhārī? Tokyo: The International Research Institute for Advanced Buddhology, Soka University, vol. 16, pp. 171-88.

Karashima, Seishi. 2013b. A Study of the Language of Early Chinese Buddhist Translations: A Comparison between the Translations by Lokakșema and Zhi Qian. Tokyo: The International Research Institute for Advanced Buddhology, Soka University, vol. 16, pp. $273-88$.

Karashima, Seishi. 2016. Features of the Underlying Language of Zhi Qian's Chinese Translation of the Vimalakīrtinirdeśa. In Guiding Lights for the Perfect: Studies on the Nature and the Development of Abhidharma Buddhism: A Commemorative Volume in Honor of Prof. Dr. Kenyo Mitomo for his 70th Birthday. Tokyo: Sankibo Busshorin, pp. 607-30.

Katsuzaki, Yūgen 勝崎裕彦. 1985. Shiken no yakugo no kenkyū-Daimyōdōkyō no yakugo bunseki 支謙の訳語の研究(一) - 『大明度 経』の訳語分析. 大正大学綜合仏教学研究所年報 7: 67-93.

Kern, Martin. 2003. Western Han Aesthetics and the Genesis of the Fu. Harvard Journal of Asiatic Studies 63: 383-437. [CrossRef]

Knechtges, David R. 1976. The Han Rhapsody: A Study of the Fu of Yang Hsiung, 53 BC-AD 18. Cambridge: Cambridge University Press.

Lancaster, Lewis R. 1969. The Chinese Translation of the Asțasāhasrikā-Prajñāāaramitā-Sūtra Attributed to Chih Ch'ien 支蕉. Monumenta Serica 28: 246-57. [CrossRef]

Maas, Philipp A. 2020. Sarvāstivāda Buddhist Theories of Temporality and the Pātañjala Yoga Theory of Transformation (pariṇāma). Journal of Indian Philosophy 48: 963-1003. [CrossRef]

Nattier, Jan. 2003. The Ten Epithets of the Buddha in the Translations of Zhi Qian 支謙. Tokyo: The International Research Institute for Advanced Buddhology, Soka University, vol. 6, pp. 207-50.

Nattier, Jan. 2005. The Proto-History of the Buddhavatamsaka: The Pusa benye jing 菩薩本業綴 and the Dousha jing 少沙經. Tokyo: The International Research Institute for Advanced Buddhology, Soka University, vol. 8, pp. 323-60.

Nattier, Jan. 2007a. Indian Antecedents of Huayan Thought: New Light from Chinese Sources. In Reflecting Mirrors: Perspectives on Huayan Buddhism. Edited by Imre Hamar. Wiesbaden: Harrassowitz Verlag, pp. 109-38.

Nattier, Jan. 2007b. A Reassessment of the dates and translator attributions of the Laonuren jing 老女人經 (T559) and the Laomu jing 老母經 (T561). Tokyo: The International Research Institute for Advanced Buddhology, Soka University, vol. 10, pp. 529-32.

Nattier, Jan. 2008a. Who Produced the Da mingdu jing 大明度綵(T225)? A Reassessment of the Evidence. Journal of the International Association of Buddhist Studies 31: 295-337.

Nattier, Jan. 2008b. A Guide to the Earliest Chinese Buddhist Translations Texts from the Eastern Han 東漢 and Three Kingdoms 三國 Periods. Tokyo: The International Research Institute for Advanced Buddhology at Soka University.

Nattier, Jan. 2008c. Heaven Names in the Translations of Zhi Qian. Tokyo: The International Research Institute for Advanced Buddhology, Soka University, vol. 12, pp. 101-22.

Nattier, Jan. 2019. Zhi Qian. In Brill's Encyclopedia of Buddhism. Volume Two. Edited by Jonathan A Silk, Lucia Dolce, Oskar Von Hinüber and Vincent Eltschinger. Leiden: Brill, pp. 818-25.

Park, Jungnok. 2008. A New Attribution of the Authorship of T5 and T6 Mahāparinirvānasūtra. Journal of the International Association of Buddhist Studies 31: 339-67.

Park, Jungnok. 2012. How Buddhism Acquired a Soul on the Way to China. Edited by Richard Gombrich. Sheffield: Equinox.

Pischel, Richard. 1981. A Grammar of the Prākrit Languages, 2nd rev. ed. Delhi: Motilal Banarsidass.

Pradhan, Prahlad. 1967. Abhidharmakosabhasyam of Vasubandhu. Patna: K. P. Jayaswal Research Institute.

Saitō, Takanobu 齊藤隆信. 2000. Shiken to Kumarajū yaku butten ni okeru ge no shiritsu 支謙と鳩摩羅什仏典における 偈の詩律. 仏教 史学研究 43: 70-91.

Strauch, Ingo. 2009. Inscribed Objects from Greater Gandhāra. Bulletin of the Asia Institute 23: 209-19.

Study Group on Buddhist Sanskrit Literature (SGBSL). 2004. Vimalakīrtinirdeśa: Transliterated Sanskrit Text Collated with Tibetan and Chinese Translations. Tokyo: The Institute for Comprehensive Studies of Buddhism, Taisho University.

Sun, Changwu 孫昌武. 2006. The Contribution of Buddhism to the Development of the Chinese Language and Linguistics. In Studies in Chinese Language and Culture: Festschrift in Honour of Christoph Harbsmeier on the Occasion of his 60th Birthday. Edited by Christoph Anderl and Halvor Eifring. Oslo: Hermes Academic Publication, pp. 331-53. 
Tang, Yongtong 湯用肜. 1938. Han Wei Liangjin Nanbeichao fojiao shi 漢魏兩亞南北朝佛教史. Available online: https://taiwanebook.ncl. edu.tw/zh-tw/book/NCL-9910006706/reader (accessed on 18 February 2021).

Vaidya, Parashuram Lakshman. 1960. Aștasāhasrikā Prajūāpāramitā with Haribhadra's Commentary Called Āloka. Darbhanga: Mithila Institute.

Vetter, Tilmann. 2012. A Lexicographical Study of An Shigao's and His Circle's Chinese Translations of Buddhist Texts. Tokyo: The International Institute for Buddhist Studies.

Zacchetti, Stefano. 2005. In Praise of the Light: A Critical Synoptic Edition with an Annotated Translation of Chapters 1-3 of Dharmarakșa's Guang zan jing 光灒經, Being the Earliest Chinese Translation of the Larger Prajñāāramitā. Tokyo: International Research Institute for Advanced Buddhology at Soka University.

Zacchetti, Stefano. 2008. A “New” Early Chinese Buddhist Commentary: The Nature of the Da anban shouyi jing 大安般守意經 T 602 Reconsidered. Journal of the International Association of Buddhist Studies 31: 421-84.

Zacchetti, Stefano. 2010. Some Remarks on the Authorship and Chronology of the Yin chi ru jing zhu 陰持入經註: The Second Phase in the Development of Early Chinese Buddhist Exegetical Literature. In Buddhist Asia 2: Papers from the Second Conference in Buddhist Studies, Held in Naples, Italy, June 2004. Kyoto: Italian School of East Asian Studies, pp. 141-98.

Zürcher, Erik. 2007. The Buddhist Conquest of China: The Spread and Adaptation of Buddhism in Early Medieval China. Leiden: Brill. First published 1959.

Zürcher, Erik. 2013. Buddhist Influence on Early Daoism: A Survey of Scriptural Evidence. In Buddhism in China: Collected Papers of Erik Zürcher. Edited by Jonathan A. Silk. Leiden: Brill, pp. 105-64. First published 1980. 